\title{
SISTEM NOKEN DI PROVINSI PAPUA: STUDI PUTUSAN MK NOMOR 47-81/PHPU.A-VII/2009
}

\author{
Tri Mulyani, A. Heru Nuswanto, Sukimin \\ Fakultas Hukum, Universitas Semarang, Semarang \\ trimulyani@usm.ac.id
}

\begin{abstract}
ABSTRAK
Tujuan dalam penulisan artikel ini adalah untuk menganalisis dasar pertimbangan hukum hakim MK dalam Putusan MK No. 47-81/PHPU.A-VII/2009 terkait dengan legitimasi sistem noken di Provinsi Papua, berserta implikasinya. Tujuan ini didasari kenyataan bahwa sistem pemilu di Indonesia dilaksanakan berdasarkan demokrasi Pancasila, dengan asas Luber-Jurdil, namun jika ada satu daerah yang melaksanakan berbeda dengan daerah lainnya, maka akan menimbulkan pro dan kontra di masyarakat, yaitu di Provinsi Papua, dengan menggunakan sistem noken, hingga berujung sengketa pemilu di Mahkamah Konstitusi. Metode yang dipergunakan adalah yuridis normatif, dengan analisis data kualitatif. Hasil analisa menunjukkan bahwa dasar pertimbangan hukum hakim konstitusi dalam Putusan MK No 47-81/PHPU.AVII/2009 terkait dengan legitimasi sistem Noken Di Provinsi Papua merujuk pendapat Bagir Manan bahwa dalam setiap putusan, wajib mengandung unsur yuridis, sosiologis dan filosofis tidak terpenuhi, salah satunya adalah unsur yuridis, yaitu mengenai tata cara pelaksanaan pemilu dengan sistem Noken sebagai pengganti kotak suara dan pengambilan suara secara transparan dengan prosedur musyawarah dan kemudian menyerahkan segala putusan kepada kepala suku, tidak sesuai dengan sistem pemilu nasional yang tata caranya didasarkan pada Pasal 22E Ayat (1) UUD NRI Tahun 1945 yaitu Pemilu dilaksanakan secara Luber-Jurdil. Unsur sosiologis dapat terlihat pada kenyataan bahwa pemerintah memberikan perlindungan dan penghormatan sebagai daerah istemewa dan memberikan legitimasi sistem noken. Secara filosofis tercermin pada saat Mahkamah Konstitusi mengesampingkan peraturan tertulis demi menegakkan keadilan bagi masyarakat hukum adat yang masih hidup di wilayah pegunungan. Adapun implikasinya bahwa putusan MK, adalah sah dan bersifat erga omnes, sehingga secara nasional, akan tetap hidup dan berkembang di tengah-tengah masyarakat adat Papua.
\end{abstract}

Kata Kunci : analisis; sistem noken; putusan; mahkamah konstitusi 


\title{
NOKEN SYSTEM IN PAPUA PROVINCE: STUDY OF THE CONSTITUTIONAL COURT NUMBER 47- 81/PHPU.A-VII/2009
}

\author{
Tri Mulyani, A. Heru Nuswanto, Sukimin \\ Fakulty of Law, Semarang University, Semarang \\ trimulyani@usm.ac.id
}

\begin{abstract}
The purpose of the discussion of this article is to review the legal considerations of the Constitutional Court justices in the Constitutional Court Decision No. 47-81 I PHPU.A-VII / 2009 related to the noken legitimacy system in Papua Province, along with their implications. This goal is based on the fact that electoral system in Indonesia is carried out through Pancasila Democracy, with the principle of LuberJurdil, but if there is one region that implements differently from other regions, it will cause pros and cons in the community, in Papua Province, using the noken system, until the election dispute ends in Constitutional Court. The method used is normative juridical, with qualitative data analysis. The results of the analysis that prove the rationale of the Constitutional Justice in the Constitutional Court Decision NO 47-81 / PHPU.A-VII / 2009 related to the Noken legitimacy system in Papua Province examines Bagir Manan in each decision, must contain juridical, sociological and philosophical requirements, one of which is fulfilled non-juridical, namely about the procedures for organizing elections with the Noken system as a ballot box and taking transparent votes with deliberation procedures and then containing all the decisions for the tribal chief, not in accordance with the electoral system 22E Paragraph (1) of the 1945 Constitution of the Republic of Indonesia that is, the elections are held in a round-up. No sociological can be seen when it comes to giving government and respect as a privileged area and providing a system of noken legitimacy. Philosophically, it was issued when the Constitutional Court ruled out the legal regulations that apply to indigenous and tribal peoples who still live in the mountains. While the implication is that the Constitutional Court's ruling, it is valid and applies erga omnes, so that nationally, it will remain alive and thrive among indigenous Papuans.
\end{abstract}

Keywords: analysis; noken system; decision; constitutional court 
p-ISSN : 2541-2345, e-ISSN : 2580-8842

\section{PENDAHULUAN}

\section{A. Latar Belakang}

Berbicara tentang pemilu, maka tidak terlepas dari pembahasan demokrasi, karena keduanya menurut Arbi Sanit tidak dapat dipisahkan dalam pengkajiannya, "Pemilu merupakan institusi yang mengejawentahkan demokrasi”. 'Bahkan lebih lanjut menurut Valentino Larcinese menyatakan bahwa "Tingkatan partisipasi dalam pemilu merupakan ukuran terhadap kualitas demokrasi itu sendiri". ${ }^{2}$ Demokrasi berkembang pada abad XX. ${ }^{3}$ Demokrasi berasal dari bahasa Yunani, yaitu "demos" dan "kratos". Demos artinya rakyat, dan kratos adalah pemerintahan (rule) atau dapat pula dimaknai dengan kekuasaan (strength). ${ }^{4}$ Sehingga dapat dimaknai secara sederhana bahwa demokrasi dapat diberi makna sebagai pemerintahan yang kedaulatannya terletak pada rakyat banyak. ${ }^{5}$

Upaya membentuk sebuah negara demokrasi, di dalam sebuah negara yang plural, merupakan pekerjaan sulit. Secara ideal dalam pelaksanaan pemerintahan sebuah negara harus melibatkan peran rakyat. Menurut Lijpart, peran rakyat ini tidak bisa seutuhnya, sehingga pembatasan peran rakyat dalam derajat tertentu harus dilakukan untuk mewujudkan asas demokrasi. ${ }^{6}$ Pembatasan ini melahirkan konsep pengisian pemerintahan yang ditentukan oleh rakyat melalui mekanisme tertentu. Menurut Harris G Waren, Harry D, Leineweber dan Ruth O. M. Anderson, dinyatakan bahwa memang pembatasan itu, perlu dilakukan karena didasari kebutuhan dari rakyat itu sendiri.

Menurut Waren, Kebutuhan akan pemerintahan itu karena "we must have an organization that will do for us those things each of us cannot do alone or that can be done better by a group". 7 Sehingga keberadaan sebuah pemerintahan memudahkan

\footnotetext{
${ }^{1}$ Arbi Sanit, 2009, Sistem Pemilihan Umum dan Perwakilan Politik, dalam Andy Ramses M, Politik dan Pemerintahan Indonesia, Masyarakat Ilmu Pemerintahan Indonesia, Jakarta, hal 213.

${ }^{2}$ Mahkamah Konstitusi Republik Indonesia, 2010, Hukum Acara Mahkamah Konstitusi, Sekretariat Jenderal dan Kepaniteraan Mahkamah Konstitusi, Jakarta, hal 213.

${ }^{3}$ Affan Sulaeman, "Demokrasi, Partai Politik, dan Pemilihan Kepala Daerah". Cosmogov Jurnal Ilmu Pemerintahan. Volume. 1 Nomor 1, April 2015, Fakultas Ilmu Sosial Dan Ilmu Politik Universitas Padjadjaran, Bandung, hal 13. DOI : https://doi.org/10.24198/cosmogov.v1i1.11857

${ }^{4}$ Op. Cit., Mahkamah Konstitusi, hal 213.

${ }^{5}$ Ibid.

${ }^{6}$ Ibid., hal 214.

${ }^{7}$ Ibid, hal 214-215.
} 
kinerja rakyat dalam mewujudkan kesejahteraan hidup mereka dalam arti yang menyeluruh. Negara yang direpresentasikan kepada pemerintah dibentuk dengan harapan mampu menciptakan kondisi terbaik bagi rakyat. Pemerintah yang mengupayakan kebaikan bagi rakyatnya itulah yang menjadi impian rakyat. Sehingga adagium Abraham Lincoln bahwa "Pemerintahan itu berasal dari rakyat dan untuk rakyat", itu benar-benar wujud. ${ }^{8}$ Rakyat memang membutuhkan pemerintahan yang memiliki kehendak untuk menyejahterakan rakyatnya. Kebutuhan akan pemerintahan tersebut memerlukan mekanisme pemilihan khusus agar pemerintahan yang terpilih dapat menjalankan harapan dari pilihannya. Dalam perkembangan teori demokrasi dan mekanisme pemilihan pemerintahan yang mewakili rakyat itu lahirlah Pemilihan Umum. ${ }^{9}$

Pemilihan umum berasal dari kata "general election", dalam Kamus Hukum Black bermakna sebuah pemilihan yang dilaksanakan dalam periode waktu tertentu dan dilakukan untuk mengisi seluruh kursi (legislatif dan eksekutif). ${ }^{10}$ Kata election dalam Kamus Hukum Black bermakna sebuah proses memilih seseorang untuk menjabat sebuah posisi tertentu. ${ }^{11}$ Di Indonesia, terkait dengan pemilu diatur melalui Undang-Undang Nomor 7 Tahun 2017 tentang Pemilihan Umum (UU Pemilu).

Pemilihan umum yang selanjutnya disebut pemilu berdasarkan Pasal 1 Angka 1 UU Pemilu, dijelaskan bahwa sarana kedaulatan rakyat untuk memilih anggota DPR, anggota DPD, presiden dan wakil presiden, dan untuk memilih anggota DPRD, yang dilaksanakan secara Luber-Jurdil dalam NKRI. Pelaksanaan pemilu berpedoman asas pemilu yang diatur pada Pasal 22E Ayat (1) UUD NRI Tahun 1945 yang dijabarkan dalam Pasal 2 dan 3 UU Pemilu, yaitu:

1. Langsung, artinya rakyat pemilih mempunyai hak secara langsung memberikan suaranya sesuai dengan kehendak hati nuraninya tanpa perantara.

\footnotetext{
${ }^{8}$ Ibid.

${ }^{9}$ Ibid.

${ }^{10} \mathrm{Ibid}$, hal 216.

${ }^{11}$ Ibid.
} 
2. Umum, artinya semua warga negara yang telah berusia 17 tahun / telah menikah berhak memilih dan telah berusia 21 tahun berhak dipilih dengan tanpa ada diskriminasi..

3. Bebas, artinya rakyat pemilih berhak memilih menurut hati nuraninya tanpa ada pengaruh, tekanan/paksaan dari siapapun/dengan apapun.

4. Rahasia, artinya rakyat pemilih dijamin oleh peraturan tidak akan diketahui oleh pihak siapapun dan dengan jalan apapun siapa yang dipilihnya atau kepada siapa suaranya diberikan.

5. Jujur, artinya dalam penyelenggaraan pemilu, penyelenggara pelaksana, pemerintah dan Parpol peserta pemilu, pengawas dan pemantau termasuk pemilih serta semua pihak yang terlibat secara tidak langsung gharus bersikap jujur sesuai peraturan perundang-undangan yang berlaku.

6. Adil, artinya dalam penyelenggaraan pemilu setiap pemilihan dan partai politik peserta pemilu mendapat perlakuan yang sama serta bebas dari kecurangan pihak manapun. $^{12}$

Namun terjadi fenomena pelaksanaan pemilu yang menggunakan metode pemungutan suara dengan jalan "Kesepakatan Warga" atau "Aklamasi" yang dikenal dengan istilah "Noken". ${ }^{13}$ Noken adalah tas (kantung) tradisional masyarakat Papua. Dalam konteks demokrasi pemilu, noken dipakai sebagai tempat menampung suara pengganti kotak suara. ${ }^{14}$ Mekanisme dan proses pemilu dengan menggunakan Noken dapat dikatakan sangat unik, sangat jauh berbeda dengan prosedural pemilihan nasional, yang laksanakan serentak di seluruh wilayah NKRI. Dalam Pemilu, Noken model masyarakat adat Papua, proses pengambilan suara dilakukan oleh kepala suku. ${ }^{15}$ Di sini kepala suku berperan sangat penting, yaitu sebagai eksekutif pemegang kedaulatan suara

${ }^{12}$ Frenki, “Asas-Asas Dalam Pelaksanaan Pemilihan Umum di Indonesia Menurut Fiqh Siyasah”. Jurnal Hukum Ekonomi Syari'ah. Volume 8, Nomor 1 Tahun 2016, Universitas Muhamadiyah Purwokerto, 2016, Puwokerto, hal. 57-58. (DOI:https://doi.org/10.24042/asas.v8i1.1223).

${ }^{13}$ Hasyim Asy'ari, Pemilu 2019, KPU Ingin Penggunaan Sistem Noken Berkurang (Jakarta: Tempo Co, 24 April 2018), 2018.

${ }^{14}$ Ibid.

${ }^{15}$ Oly Viana Agustine, “Implementasi Noken Sebagai Hukum Tidak Tertulis Dalam Sistem Hukum Nasional”. Jurnal Rechtsvinding. Vol 8, Nomor 1 April 2019, Badan Pembinaan Hukum Nasional, 2019, Jakarta, hal 70. 
rakyat yang kemudian dimusyawarahkan dan disepakati atau disetujui bersama masyarakat adat (aklamasi).

Metode pemungutan suara dengan sistem noken ini terlegitimasi berdasarkan pendapat yudisial MK dalam Putusan No. 47-81/PHPU.A-VII/2009 dalam perkara perselisihan Pemilu di Kabupaten Yahukimo, dinyatakan:

"Menimbang bahwa Mahkamah berpandangan, Pemilu di Kab Yahukimo tidak diselenggarakan berdasarkan peraturan perundang-undangan yang berlaku (UU No 10 Tahun 2008 yang telah diubah terakhir dengan Peraturan Pemerintah Pengganti UU Nomor 1 Tahun 2009 tentang Perubahan Atas Undang-Undang Nomor 10 Tahun 2008 tentang Pemilihan Umum Anggota DPR, DPD, dan DPRD) karena tidak dengan cara pencontrengan surat suara, melainkan dengan "kesepakatan warga" atau "aklamasi" dan hasilnya tetap ke dalam rekapitulasi hasil pemungutan suara yang dilaksanakan pada tanggal 6 Mei 2009 di KPU Provinsi Papua. ${ }^{16}$

Sehubungan dengan putusan MK No. 47-81/PHPU.A-VII/2009, sistem noken mempunyai legitimasi. Implikasi dari legitimasi MK tersebut, praktek noken ini menuai kriktik tajam, karena sistem ini tidak menerapkan secara prosedural praktek demokrasi yang sesungguhnya. Sistem noken ini berpotensi menimbulkan distorsi, penyelewengan atau pembelokan suara oleh perwakilan warga. Artinya bahwa sistem noken ini membunuh hak perorangan untuk memilih dengan hati nurani, siapa yang harus dipilih, karena sistem noken ini terdiri atas 2 pola, yaitu: pertama, Pola Big Man yaitu pilihan suara seluruh anggota suku diwakilkan kepada kepala suku masing-masing; ${ }^{17}$ kedua, sistem noken gantung atau ikat di mana masyarakat dapat melihat suara yang telah disepakati masuk kedalam yang sebelumnya telah ditetapkan. ${ }^{18}$ Kedua sistem noken tersebut dapat mengklaim suara salah satu kampung dan diberikan ke salah satu calon dari beberapa calon. Sistem noken ini setiap pasangan calon sejak awal sudah dapat diketahui

\footnotetext{
${ }^{16}$ Putusan Mahkamah Konstitusi No. 47-81/PHPU.A-VII/2009, hal 46.

${ }^{17}$ Waluyo, "Model Pemilu Dengan Sistem Noken Berbasis Budaya dan Kearifan Lokal”. Jurnal Hukum Samudera Keadilan. Volume 13 Nomor 2 Juli-Desember 2018, Fakultas Hukum Universitas Samudra, 2018, Langsa. hal 296. DOI: $\underline{\text { https://doi.org/10.33059/jhsk.v13i2.1065 }}$ 
menang atau kalah tanpa menunggu hari pemungutan suara, karena dukungan setiap suku bisa diketahui dari awal, sehingga sistem noken ini harus dihilangkan.

Namun justifikasi untuk legitimasi penerapan noken ini, oleh MK dalam Putusan No. 47-81/PHPU.A-VII/2009 tanggal 09 Juni 2009:

"Menimbang bahwa Mahkamah dapat memahami dan menghargai nilai budaya yang hidup di kalangan masyarakat Papua yang khas dan menyelenggarakan Pemilu dengan cara atau sistem "kesepakatan warga" atau "aklamasi”. Mahkamah menerima cara pemilihan kolektif ("kesepakatan warga" atau "aklamasi") yang telah diterima masyarakat Kabupaten Yahukimo tersebut, karena jika dipaksakan Pemilu sesuai dengan peraturan perundang-undangan yang berlaku dikhawatirkan akan timbul konflik diantra kelompok-kelompok masyarakat setempat. Mahkamah berpendapat, agar sebaiknya mereka tidak dilibatkan / dibawa ke sistem persaingan / perpecahan di dalam dan antar kelompok yang dapat mengganggu harmoni yang telah mereka hayati. $^{19}$

Berdasarkan uraian tersebut dapat dicermati bahwa sistem noken ini jelas bertentangan dengan asas "Luber-Jurdil" sebagai asas konstitusi, ${ }^{20}$ namun pendapat yudisial MK dalam Putusan No. 47-81/PHPU.A-VII/2009, justru memberikan legitimasi dalam pelaksanaannya. ${ }^{21}$

Terkait dengan penelitian tentang sistem noken banyak sekali yang mencoba untuk mengkajinya, karena sistem noken ini memang unik dan sangat menarik untuk diperbincangkan, seperti halnya dalam artikel Methodius Kossay, yang membahas tentang bagaimana sistem noken diterapkan dalam penyelenggaraan pemilu di Kabupaten Jayawijaya Provinsi Papua, dan apakah sesuai dengan asas-asas pemilu. ${ }^{22}$ Peneltian dari Nelwan Ronsumbre yang mengkaji tentang sistem nokem yang dianggap sebagai keaifan

\footnotetext{
${ }^{19}$ Op. Cit., Putusan MK, hal 46.

${ }^{20}$ Yerianto Tarima, Piers Andreas Noak dan Muhammad Ali Azhar, Peran Kepala Suku Dalam Sistem Noken Pada Pemilukada Di Distrik Kaтu Kabupaten Dogiyai Provinsi Papua Tahun 2013 (Nusa Tenggara Timur, E Journal Politika Volume I Nomor 1, Fakultas Ilmu Sosial dan Ilmu Politik Universitas Udayana, 2016, Denpasar, hal 1.

${ }^{21} \mathrm{Ibid}$

${ }^{22}$ Methodius Kossay, "Pemilu Sistem Noken Dalam Demokrasi Indonesia (Studi Kasus di Kabupaten Jayawijaya Provinsi Papua)”. Jurnal Serviens in Lumine Verietas, Fakultas Hukum Universitas Atma Jaya Yogyakarta, 2014, Yogyakarta, hal 5.
} 
lokal dengan menitikberatkan peneltian pada sistem pemilu, demokrasi deliberatif dan hak asasi politik warga negara. ${ }^{23}$ Namun dalam penelitian ini akan dikaji lebih dalam secara yuridis normatif terkait Putusan MK NO 47-81/PHPU.A-VII/2009 terkait dengan legitimasi sistem noken di Provinsi Papua, dan implikasi pasca Putusan MK NO 4781/PHPU.A-VII/2009 terkait dengan keberadaan sistem noken di Provinsi Papua.

\section{B. Permasalahan}

Fokus permasalahan yang dikaji dalam artikel ini adalah:

1. Bagaimanakah analisis mengenai dasar pertimbangan hukum Hakim Konstitusi dalam putusan Mahkamah Konstitusi No 47-81/PHPU.A-VII/2009 terkait dengan legitimasi sistem noken di Provinsi Papua ?

2. Bagaimanakah implikasi pasca putusan Mahkamah Konstitusi No 47-81/PHPU.AVII/2009 terkait dengan keberadaan sistem noken di Provinsi Papua?

\section{Metode Penelitian}

Jenis penelitian hukum yang digunakan adalah penelitian yuridis normatif, yakni penelitian yang difokuskan untuk mengkaji penerapan kaedah-kaedah atau norma-norma hukum positif. ${ }^{24}$ Jenis ini dipergunakan, mengingat bahwa obyek dalam penelitian ini adalah Putusan MK No 47-81/PHPU.A-VII/2009. Data yang dibutuhkan adalah data sekunder, diambil dengan cara penelitian kepustakaan (Library Research). ${ }^{25}$ Metode analisis data dilakukan secara kualitatif, yaitu metode analisis yang pada dasarnya mempergunakan pemikiran logis, analitis, dengan logika induksi atau deduksi dengan analogi/intepretasi, komparasi dan sejenis itu. ${ }^{26}$ Sehingga bahan hukum yang telah diperoleh diuraikan dan dihubungkan sedemikian rupa kemudian ditarik kesimpulan secara induktif.

\section{PEMBAHASAN}

\footnotetext{
${ }^{23}$ Nelwan Ronsumbre, “Sistem Noken Papua : Manifestasi Demokrasi Berbasis Kearifan Lokal”. Jurnal Sosial Politik Volume 5 Nomor 2 Tahun 2019, Universitas Padjajaran, 2019, Bandung, hal 261. DOI: https://doi.org/10.22219/sospol.v5i2.7388 hal 295

${ }^{24}$ Johnny Ibrahim, 2005, Teori Dan Metodologi Penelitian Hukum Normatif, Edisi Revisi, Bayumedia Publishing, Malang,

${ }^{25}$ Peter Mahmud Marzuki. 2006, Penelitian Hukum, Kencana, Jakarta, hal 141.

26 Tatang A. Amirin, 1986. Menyusun Rencana Penelitian, C.V. Rajawali, Jakarta, hal 95.
} 
p-ISSN : 2541-2345, e-ISSN : 2580-8842

\section{A. Dasar Pertimbangan Hukum Hakim Konstitusi Dalam Putusan MK NO 47- 81/PHPU.A-VII/2009 Terkait Dengan Legitimasi Sistem Noken Di Provinsi Papua}

\section{Pertimbangan Hukum}

Sebelum menjatuhkan putusan, Mahkamah Konstitusi, menyampaikan pendapatnya, yaitu:

1. Tentang Eksepsi

MK menyampaikan pendapatnya bahwa:

"MK keberatan terhadap jawaban Termohon dan turut Termohon terdapat eksepsi yang pada pokoknya berkaitan dengan jawaban yang menyatakan bahwa permohonan Pemohon telah lewat tenggang waktu yang telah ditentukan, Pemohon tidak termasuk objek perselisihan hasil pemilu, dan permohonan Pemohon kabur (obscuur libel) dan/atau prematur, karena dengan bukti (3.6) dan (3.7), oleh karenanya Eksepsi Termohon dan Turut Termohon dikesampingkan"

2. Tentang Pokok Permohonan

Setelah mencermati permohonan dan keterangan para Pemohon, Jawaban Termohon dan Turut Termohon, bukti-bukti tertulis, serta keterangan saksi dari para pihak yang telah di dengar di persidangan, MK berpendapat bahwa terdapat fakta hukum sebagai berikut:

a. Pemungutan suara di Provinsi Papua tidak dapat dilaksanakan pada tanggal 9 April 2009, karena terjadi keterlambatan distribusi logistik. Dari 6.543 TPS di Provinsi Papua terdapat 150 TPS termasuk 90 TPS di Kab. Yahukimo yang tidak melaksanakan Pemilu tanggal 9 April 2009, dan Pemilu baru dapat dilaksanakan pada tanggal 12 April 2009. Untuk di Kab. Yahukimo terdapat 51 Panitia Pemilihan Distrik yang terdiri atas 670 TPS.

b. Rekapitulasi hasil penghitungan suara di Provinsi Papua mulai dari tingkat TPS, PPD, Kabupaten, dan Provinsi berlangsung selama 14 hari, yaitu mulai tanggal 23 
April 2009 sampai tanggal 6 Mei 2009, untuk di Kabupaten Yahukimo dilaksanakan pada tanggal 6 Mei 2009 di KPU Provinsi Papua.

c. Pemilu di Kab. Yahukimo, umumnya tidak dilakukan dengan cara pencontrengan pada surat suara, melainkan dilakukan dengan cara "Aklamasi", oleh setiap perwakilan kelompok, dan ternyata hasilnya tetap dimasukkan ke dalam rekapitulasi hasil penghitungan suara yang dilaksanakan pada tanggal 6 Mei 2009, di KPU Provinsi Papua.

d. Terjadi perbedaan penghitungan suara hasil Pemilu untuk Calon Anggota DPD di Kab. Yahukimo di Distrik Kurima, Tangma, Uka, Mugi, Yogosem, Werima, Pasema, Samenage, Silimo, Hogio, Amuna, Musaik, Suru-Suru dan Distrik Wusama.

e. Pada Distrik Ninia, Holuwon, Soba, Kayo, Hilipuk, Sobaham, Kwikma, Kabianggema, Lolat, Soloikma, Duram, Korupun, Sela, Kwelamdua, Langda, Bomela, S"mtamon, Dekai, Sumo, Obio, Seradala, Anggruk, Walma, Pronggoli, Panggema, Ubahak, Yahuliambut, Kosarek, Nipsam, Talambo, Endomen, Fuldama, Kona, Dirwemmna, Nalca, Ubaihi dan Distrik Hereapin tidak diselenggarkan Pemilu untuk Calon Anggota DPD. Hal tersebut yang menyebabkan Rapat Pleno Rekapitulasi Penghitungan Suara Hasil Pemilu Provinsi Papua pada tanggal 6 Mei 2009 di KPU Provinsi Papua, khusus untuk Kabupaten Yahukimo mengalami deadlock, sehingga harus discors hingga 2 kali, karena terdapat keberatan dari saksi partai politik dan Calon Anggota DPD. Untuk penyelesainnya, maka dibentuklah Tim kecil yang terdiri dari 13 orang yang masing-masing 5 dari KPU Kab. Yahukimo, 1 dari KPU Provinsi Papua, Ketua Panwaslu Provinsi Papua, dan 5 dari saksi Parpol, yang dalam rapat tersebut, Bupati dan Ketua DPRD Kab. Yahukimo ikut hadir, yang notabene mereka tidk punya hak ikut rapat tersebut. Rapat tersebut tidak mencapai kesepakatan, mengingat waktu terbatas, sehingga Ketua KPU Provinsi Papua tetap menetapkan rekapitulasi penghitungan suara dengan tetap 
mempersilahkan kepada pihak-pihak yang mengajukan keberatan sebagai sengketa pemilihan umum di MK.

f. MK berpendapat bahwa Pemilu di Kabupaten Yahukimo tidak diselenggarakan berdasarkan peraturan perundang-undangan yang berlaku yaitu UU No. 10 Tahun 2008 tentang Pemilu Anggota DPR, DPD dan DPRD, yang telah diubah terakhir dengan Peraturan Pemerintah Pengganti UU Nomor 1 Tahun 2009 tentang perubahan atas UU Nomor 10 Tahun 2008 tentang Pemilu Anggota DPR, DPD dan DPRD, karena tidak dengan pencontrengan surat suara, melainkan dengan "Kesepakatan Warga" atau "Aklamasi" dan hasilnya tetap dimasukan ke dalam rekapitulasi hasil penghitungan suara yang dilaksanakan pada tanggal 6 Mei 2009 di KPU Provinsi Papua. Dalam hal ini MK dapat memahami dan menghargai nilai budaya yang hidup dikalangan Masyarakat Papua yang khas dalam menyelenggarakan Pemilihan Umum dengan cara atau sistem dengan "Kesepakatan Warga" atau "Aklamasi". Mahkamah Konstitusi menerima cara pemilihan kolektif ("Kesepakatan Warga" atau "Aklamasi") yang telah diterima masyarakat Kab. Yahukimo tersebut, karena jika dipaksakan Pemilu sesuai dengan peraturan perundang-undangan yang berlaku dikhawatirkan akan timbul konflik diantara kelompok - kelompok masyarakat setempat. MK berpendapat bahwa, agar sebaiknya mereka tidak dilibatkan / dibawa ke sistem persaingan / perpecahan di dalam dan antar kelompok yang dapat mengganggu harmoni yang telah mereka hayati.

g. Penerimaan Pemilu dengan cara atau sistem dengan "Kesepakatan Warga" / "Aklamasi" ini tentunya harus dilaksanakan dengan baik oleh penyelenggara, panitia Pemilu, dalam hal ini KPU Kabupaten, akan tetapi dalam kasus aquo ternyata KPU Yahukimo telah melakukan pelanggaran hukum secara terstruktur dan masif, oleh sebab itu, meskipun menerima caranya yang khas, tetapi karena untuk distrik-distrik tertentu, penyelenggaraannya telah melakukan pelanggaran 
hukum secara terstruktur dan masif, maka demi keadilan, MK menafikan hasil rekapitulasi tersebut, agar KPU Kab. tetap melaksanakan kewajiban hukumnya.

h. MK menilai bahwa pada Distrik Ninia, Holuwon, Soba, Kayo, Hilipuk, Sobaham, Kwikma, Kabianggema, Lolat, Soloikma, Duram, Korupun, Sela, Kwelamdua, Langda, Bomela, S"mtamon, Dekai, Sumo, Obio, Seradala, Anggruk, Walma, Pronggoli, Panggema, Ubahak, Yahuliambut, Kosarek, Nipsam, Talambo, Endomen, Fuldama, Kona, Dirwemmna, Nalca, Ubaihi dan Distrik Hereapin, ternyata tidak diselenggarakan Pemilu dan telah terjadi perbedaan rekapitulasi penghitungan hasil Pemilu pada Distrik Kurima, Tangma, Uka, Mugi, Yogosem, Werima, Pasema, Samenage, Silimo, Hogio, Amuna, Musaik, Suru-Suru dan Distrik Wusama, maka MK berpendapat bahwa sesungguhnya bahwa Pemilu merupakan wujud pelaksanaan hak politik warga negra yang paling nyata dalam demokrasi, sedangkan prinsip demokrasi itu sendiri merupakan salah satu asas yang fundamental dalam ketatanegaraan menurut UUD NRI Tahun 1945, yaitu LuberJurdil, serta merupakan hak negara untuk membangun dirinya. Oleh sebab itu, Mahkamah Konstitusi tidak dapat berdiam diri jika secara nyata terjadi pelanggaran yang masif dan terstruktur, sebab apabila dibiarkan, artinya MK tidak mampu menjaga tegaknya demokrasi, dan pelangaran serupa akan terjadi lagi. Oleh sebab itu MK tidak hanya memeriksa dan memutus dari segi kuantitatifnya saja, yaitu merekapitulasi kembali angka-angka perolehan suara yang telah ditetapkan secara resmi oleh KPU, melainkan juga dapat memerintahkan pemungutan dan/atau penghitungan suara ulang jika hal tersebut dipandang perlu, dengan memerintahkan 2 hakim konstitusi untuk menghadiri proses, guna memastikan terselenggaranya pemungutan dan penghitungan suara ulang.

\section{Analisis Dasar Pertimbangan Hukum Hakim Konstitusi Dalam Putusan MK NO 47-81/PHPU.A-VII/2009}

Dilihat dalam ketentuan Pasal 1 Ayat (3) UUD NRI Tahun 1945, bahwa Indonesia adalah negara hukum. Ketentuan tersebut, merupakan sebuah landasan 
konstitusional bahwa Indonesia adalah negara yang berdasarkan atas hukum, hukum dijunjung tinggi dan ditempakan sebagai satu-satunya aturan main dalam kehidupan bermasyarkat, berbangsa dan bernegara di segala tatanan bidang kehidupan nasional, baik dalam bidang politik, sosial, ekonomi, budaya, pertahanan dan keamanan. Selain itu, hukum juga dijadikan sebagai alat konrol agar selalu tercipta tatanan kehidupan yang aman, tertib, adil, memberikan jaminan kepastian hukum, memberikan perlindungan terhadap HAM setiap warganya, dan juga hukum memiliki peran yang sangat penting sekali terhadap penyelesaian setiap konflik yang terjadi diantara subjek hukum.

Beranjak dari landasan konstitusional bahwa Negara Indonesia adalah negara hukum, perlu diketahui juga bahwa negara Indonesia adalah negara pluralis, Artinya suatu negara yang memiliki suatu paham atau pandangan hidup yang mengakui dan menerima adanya kemajemukan atau keanekaragaman dalam kehidupan bermasyarakat, berbangsa dan bernegara. Keanekaragaman yang dimiliki Negara Indonesia meliputi berbaga macam corak, mulai corak ragam budaya, ras, 1.340 suku, 6 agama, dan golongan yang selama ini menjadi ciri sebagai jati diri, sebagai identitas Nasional Indonesia di mata dunia internasional. Keanekaragaman tersebut oleh Founding Fathers Bangsa Indonesia disatukan dengan semboyan negara adalah Bhinneka Tunggal Ika sebagai falsafah hidup bermasyarakat, berbngsa dan bernegara yang dituangkan dalam Pasal 36A UUD NRI Tahun 1945.

Sehubungan hal tersebut di atas, maka dengan mencermati upaya Negara Indonesia untuk mewujudkan masyarakat yang adil dan maknur, memajukan kesejahteraan umum dan keadilan sosial bagi seluruh rakyat Indonesia sesuai dengan cita-cita bangsa ditengahtengah pluralisme negara Indonesia, ternyata tidak semudah yang dibayangkan. Ditengah perjalanannya sering mengalami problematika yang beragam pula. Kebijakan yang dikeluarkan oleh pemerintah kadangkala dalam penerapannya bersinggungan, karena terdapat tradisi budaya yang berbeda-beda dari masing-masing daerah, salah satunya 
perselisihan pemilu dengan menggunakan sistem "kesepakatan warga" atau "aklamasi" atau "sistem noken" yang terjadi di Provinsi Papua.

Noken (kantung) adalah tas asli khas masyarakat adat Papua yang terbuat dari serat kayu asli. Noken yang memiliki nilai sejarah ini, merupakan lambang tradisi budaya yang memiliki nilai filosofis yang tinggi bagi masyarakat adat di Papua. Tradisi budaya noken ini, menjadi pro dan kontra ketika dipergunakan dalam sebuah Pemilu. Pemilu noken adalah pemilu tradisional adat Papua yang telah menjadi tradisi turun temurun yang dilakukan oleh masyarakat daerah khusus pegunungan sejak tahun 1971. Pemilihan sistem noken yang telah berlangsung lama ini, pada awalnya, tidak pernah dipermasalahkan oleh pihak manapun. Warga masyarakat yang berada di wilayahwilayah pegunungan tengah Papua melaksanakan dengan baik dan lancar tanpa konflik sama sekali, namun pemilihan sistem noken ini awalnya pada tahun 2009 dan puncaknya pada tahun 2014 menjadi sebuah permasalahan yang sangat besar dan berujung di meja pengadilan Mahkamah Konstitusi.

Tahun 2009 ini terjadi sebuah Pemilu di Kabupaten Yahukimo Papua, dan terjadilah sengketa Pemilu yang berlanjut ke MK dengan perkara Nomor 47-81/PHPU-A-VII/2009. Dalam sengketa ini pemohonnya adalah Pdt. Elion Numberi dan Hasbi Suaib. Pendeta Elion Numberi dan Hasbi Suaib mengajukan permohonan peninjauan kembali atas perhitungan nilai hasil suara yang dihitung, dan dilakukan pemungutan suara ulang. Eliton Numberi memperoleh 3.030 suara hasil dari pemungutan suara secara aklamasi, namun suara Eliton Numberi nihil ketika sampai ke KPU Provinsi Papua. Data KPU Provinsi Papua yang memperoleh suara terbanyak adalah calon DPD Paulus Yohanes yaitu 256.047. Setengah jumlah suaranya, 148.000 suara berasal dari Yahukimo, padahal 2 dapil tidak pernah ada pemungutan suara, dan pemungutan suara secara aklamasi dimenangkan oleh Eliton Numberi. Permohonan Pendeta Elion Numberi dan Hasbi Suaib ini diterima oleh Mahkamah Konstitusi dan diputuskan untuk melaksanakan pemungutan suara ulang di 37 distrik, dengan perhitungan suara ulang di 14 distrik di Kabupaten Yahukimo Propnsi Papua. 
Selanjutnya pada Pemilu presiden dan wakil presiden periode tahun 2014, semakin memanas ketika calon presiden Prabowo - Hatta mengalami kekalahan dan mengajukan permohonan ke Mahkamah Konstitusi. Sebenarnya yang dipermasalahkan dalam hal ini bukan perselisihan hasil pemilunya, namun sistem noken di Papua yang dinilai suatu sistem pemungutan suara yang syarat kecurangan, sehingga perkara Nomor 47-81/PHPUA-VII/2009 di Yakuhimo tahun 2009 yang lalu dibuka kembali. ${ }^{27}$ Namun secara yuridis MK telah dengan tegas menyatakan bahwa putusan Mahkamah Konstitusi Nomor 4781/PHPU-A/VII/2009 telah memiliki kekuatan tetap, dengan serta merta memiliki kekuatan hukum tetap dan wajib untuk dilaksanakan.

Berikut ini dapat dikemukakan analisis dari Peneliti, terkait dengan Dasar Pertimbangan Hukum Hakim Konstitusi dalam Putusan MK No. 47-81/PHPU.AVII/2009 Tentang Legitimasi Sistem Noken Di Provinsi Papua. Seorang hakim apabila hendak memutuskan sebuah perkara wajib membuat sebuah pertimbangan. Putusan yang baik hendaknya mengandung pertimbangan yang memunculkan 3 nilai yaitu yuridis, sosiologis dan filosofis. ${ }^{28}$ Hal senada dikemukakan oleh Bagir Manan, yaitu bahwa:

"Yang menjadi dasar pertimbangan hakim dalam mengambil suatu putusan dalam memutuskan perkara meliputi 3 hal yaitu putusan hakim dalam perspektif tuntutan kepastian hukum (yuridis), putusan hakim dalam perspektif tuntutan sosiologis (kemanfaatan) dan putusan hakim dalam perspektif filosofis (keadilan). ${ }^{29}$

Berikut analisisnya:

1. Pertimbangan Yuridis (Kepastian Hukum)

Kepastian hukum menekankan agar hukum atau peraturan ditegakkan sebagaimana yang diinginkan oleh bunyi hukum atau peraturannya "Fiat Justitia et pereat mundus" yang artinya bahwa meskipun dunia runtuh, hukum harus ditegakkan.

${ }^{27}$ Muhammad Fauzan Azim, "Pemilu dan Konstitusionalitas Sistem Noken”. Turast Jurnal Penelitian dan Pengapdian Volume 1 Nomor 1 Tahun 2013, Universitas Islam Negeri Imam Bonjol, 2013, Padang, hal 30-31.

${ }^{28}$ Firman Floranta Adonara, "Prinsip Kebebasan Hakim Dalam Memutus Perkara Sebagai Amanat Konstitusi". Jurnal Konstitusi, Volume 12, Nomor 2, Juni 2015, Mahkamah Konstitusi, 2015, Jakarta, hal 220. DOI: https://doi.org/10.31078/jk1222

${ }^{29}$ Bagir Manan. Menjadi Hakim Yang Baik, Makalah Pertama Kali Disampaikan Sebagai Ceramah Untuk Calon-Calon Hakim, Di Malang, 7 September 2006 dan telah dipublikasikan oleh Pusdiklat Teknis Peradilan Balitbang Diklat Kumdil MA-RI: Jakarta, 2008, hal 3-8. 
Dalam konsep ini hakim adalah corong undang-undang, artinya hukum harus dijalankan sebagaimana adanya tanpa dipengaruhi oleh faktor apapun.

Sehubungan dengan hal tersebut di atas, apabila dilihat dari perspektif yuridis (kepastian hukum) dalam konteks sengketa pemilu Noken di Yahukimo, tata cara pelaksanaan dengan menggunakan Noken sebagai pengganti kotak suara dan pengambilan suara secara transparan dengan prosedur musyawarah dan kemudian menyerahkan segala putusan kepada kepala suku, sungguh bertentangan dengan Pasal 22E Ayat (1) UUD NRI Tahun 1945 bahwa "pemilu dilaksanakan secara Luber-Jurdil setiap lima tahun sekali”. Selanjutnya begitu juga dengan tata cara pemilu yang diatur oleh Undang Undang Pemilu, beserta Peraturan KPU terkait pemilihan langsung. Ketidakserasian prosedural ini diimbangi dengan ketiadaan asas one man one vote kebebasan hak-hak individual atas satu orang, satu suara dalam pencontrengan yang dinilai melanggar HAM. Namun dalam putusan pertimbangan hakim dalam putusan MK Nomor 47-81/PHPU-A/VII/2009 hakim konstitusi membolehkan penggunaan Noken sebagai pengganti kotak suara dengan pertimbangan:

"Dari 6.543 TPS di Provinsi Papua, terdapat 150 termasuk 90 TPS di Kab. Yahukimo yang tidak melaksanakan pemilu tanggal 9 April 2009 dan pemilu baru dapat dilaksanakan pada tanggal 12 April 2009 karena keterlambatan logistik”.

Point pertimbangan selanjutnya:

"Menimbang bahwa Mahkamah dapat memahami dan menghargai nilai budaya yang hidup di kalangan masyarakat Papua yang khas dan menyelenggarakan pemilihan umum dengan cara atau sistem "kesepakatan warga" atau "aklamasi". Mahkamah menerima cara pemilihan kolektif "Kesepakatan Warga" atau "Aklamasi" yang telah diterima masyarakat Kabupaten Yahukimo tersebut, karena jika dipaksakan Pemilu sesuai dengan peraturan perundang-undangan yang berlaku dikhawatirkan akan timbul konflik diantara kelompok-kelompok masyarakat setempat. Mahkamah berpendapat, agar sebaiknya mereka tidak dilibatkan / dibawa ke sistem persaingan / perpecahan di dalam dan antar kelompok yang dapat mengganggu harmoni yang telah mereka hayati. Penerimaan atas cara yang realitis ini tentunya harus dilaksanakan dengan baik oleh penyelenggara atau panitia pemilu, dalam hal ini KPU Kabupaten, tetapi dalam kasus aquo ternyata KPU Kabupaten Yahukimo telah melakukan pelanggaran hukum secara terstruktur dan masif. Oleh sebab itu, meskipun menerima caranya yang khas, tetapi 
karena untuk distrik-distrik tertentu, penyelenggaranya telah melakukan pelanggaran secara terstruktur dan masif, maka demi keadilan mahkamah menafikan hasil rekapitulasi tersebut. ${ }^{30}$

Pengakuan MK terhadap konstitusionalitas sistem noken ini telah melahirkan suatu keadaan yang ambigu di mana terdapat dualisme sistem pemilu dalam sistem pemilu nasional yang dipraktikan. Pelaksanaan demokrasi di Indonesia seharusnya terlaksana berdasarkan asas luber jurdil yang termaktub dalam Pasal 22E Ayat (1) UUD NRI Tahun 1945, dengan hak pilih yang sama (one man one vote) ketika menunaikan hak pilihnya di bilik suara, namun universalitas pemilu ini tidak bisa diterapkan di Provinsi Papua (Yahukimo), karena masyarakat adat di Yahukimo melaksanakan pemilu dengan cara mereka sendiri yang sesuai dengan adat yang berlaku yaitu aklamasi atau istilah lain yang terkenal adalah Noken.

2. Pertimbangan Sosiologis (Kemanfaatan)

Bagi penganut teori atau konsep yang dipengaruhi oleh pandangan sosial mengenai hukum akan berkata "hakim yang baik adalah hakim yang memutus sesuai dngan kenyataan atau tuntutan sosial yang ada dalam masyarakat".

Sehubungan dengan hal tersebut di atas, maka dalam hal ini perlu diketahui bahwa pemerintah telah secara tegas menyatakan perlindungan dan penghormatan kepada masyarakat dan daerah-daerah hukum, sebagaimana diatur dalam Pasal 18B Ayat (2) UUD NRI Tahun 1945 yaitu:

"Negara mengakui dan menghormati kesatuan-kesatuan masyarakat hukum adat beserta hak-hak tradisionalnya sepanjang masih hidup dan sesuai dengan perkembangan masyarakat dan prinsip negara kesatuan republik Indonesia yang diatur dalam undang-undang". 31

Bentuk pengakuan ini dan perlindungan ini secara langsung memberikan kekuasaan dan hak masyarakat adat untuk hidup, mencari dan mengatur kehidupan sesuai dengan tuntutan peraturan atau pranata di wilayah adatnya. Propinsi Papua

\footnotetext{
${ }^{30}$ Op. Cit., Putusan MK, hal 46.

${ }^{31}$ Pasal 18B Ayat (2), Undang-Undang Dasar Negara Republik Indonesia Tahun 1945
} 
adalah daerah istimewa yang mendapat legitimasi pengakuan dalam Pasal 18 Ayat (1) UUD NRI Tahun 1945 yaitu:

"Negara mengakui dan menghormati satuan-satuan pemerintah daerah yang bersifat khusus atau bersifat istimewa yang diatur dalam undang-undang”.

Khususnya masyarakat Yahukimo merupakan salah satu wilayah istemewa yang memperoleh legitimasi langsung dari Mahkamah Konstitusi berkaitan dengan pemilu noken. Menurut Arif Hidayat (Ketua Majelis MK) menegaskan bahwa:

"Pemungutan suara dengan sistem noken masih dapat dibenarkan, namun ditegaskan kembali dalam pertimbangan hukum, mahkamah konstitusi menilai penggunaan sistem noken dalam pemilu hanya bersifat kasuistis yang pada waktu itu masih dibutuhkan oleh sebagian masyarakat di pegunungan Papua" ${ }^{32}$

Oleh karenanya Mahkamah Konstitusi berpandangan bahwa sistem noken tidak perlu dinormakan hanya berlaku ditempat dan waktu tertentu. Pandangan dari Hamdan Zoelva (Ketua MK), yaitu: "Sistem perwakilan pemilihan atau noken tidak bisa digunakan untuk pemilu maupun pemilukada daerah lainnya. MK mengakui sistem noken secara konstitusional akan tetapi sistem ini tidak bisa digeneralisasi berlaku di seluruh kabupaten/kota atau provinsi seluruh Indonesia. Putusan MK hanya berlaku untuk berperkara sesuai dengan fakta di lapangan atau kasuistis bukan melahirkan norma yang bersifat umum".

Putusan MK terhadap kasus sistem noken telah menghidupkan ekspektasi masyarakat hukum adat yang menghendaki adanya penghormatan negara terhadap identitas budaya mereka yang dijamin oleh konstitusi. Mahkamah Konstitusi telah menunjukkan bagaimana negara seharusnya menghormati, melindungi dan memajukan hak-hak tersebut selaras dengan perkembangan zaman. Sebagai salah satu pelaku kekuasaan kehakiman, Mahkamah Konstitusi proaktif dalam mengawasi dan mengontrol kekuasaan negara. karena peran Mahkamah Konstitusi tidak hanya sebagai penjaga demokrasi, namun sekaligus sebagai pelindung hak konstitusional warga

${ }^{32}$ Op.Cit, Bagir Manan 
p-ISSN : 2541-2345, e-ISSN : 2580-8842

negara, serta HAM, sehingga di saat bersamaan Mahkamah Konstitusi merupakan pengawal konstitusi.

3. Pertimbangan Filosofis (Keadilan)

Pertimbangan filosofis, lahir dari seringkali dijumpai suatu keadaan aturan hukum mengalami kekosongan hukum, konflik antar norma hukum dan norma yang kabur atau norma tidak jelas. Ketika menghadapi situasi tersebut, majelis hakim berpegang pada asas ius curia novit, di mana hakim dianggap tahu akan hukum. Berpatokan pada UU kekuasaan kehakiman, Pasal 16 Ayat (1) yang menyatakan bahwa "Hakim tidak boleh menolak suatu perkara dengan alasan tidak ada atau tidak jelas hukumnya. Ia dilarang menolak menjatuhkan putusan dengan dalih undang-undangnya tidak lengkap atau tidak jelas". Ketika menghadapi suatu hukum dalam keadaan kaku dan kabur, maka hakim memiliki kebebasan hukum. Menurut Yahya Harahap "kebebasan hakim jangan diartikan kebebasan yang tanpa batas dengan menonjolkan sikap arrognce of power dengan memperalat kebebasan yang menghalalkan segala cara, namun kebebasan tersebut relatif dengan acuan:

a. Pertama, menerapkan hukum yang bersmber dari peraturan perundang-undangan yang tepat dan benar dalam menyelesaikan kasus perkara yang sedang diperiksa, sesuai dengan asas dan statute law must prevail (ketentuan undang-undang harus diunggulkan).

b. Kedua, menafsirkan hukum yang tepat melalui cara-cara pendekatan penafsiran yang dibenarkan atau mengutamakan keadilan daripada peraturan perundangundangan, apabila ketentuan undang-undang tidak potensial melindungi kepentingan umum. Penerapan yang demikian sesuai dengan doktrin equity must prevail (keadilan harus diunggulkan).

c. Ketiga, kebebasan untuk mencari dan menemukan hukum (recht vinding), dasardasar dan asas-asas hukum melalui doktrin ilmu hukum, norma hukum tidak tertulis (hukum adat), yurisprudensi maupun melalui pendekatan realisme yakni mencari 
dan menemukan hukum yang terdapat pada nilai ekonomi, kemanfaatan, moral, agama, kepatutan dan kelaziman. ${ }^{33}$

Sehubungan dengan hal tersebut diatas, seorang hakim dalam putusannya agar terwujud rasa keadilan dari hukum, maka hakim wajib terjun ke lapangan untuk menghayati, menggali nilai-nilai serta melihat kenyataan yang terjadi di masyarakat. Seperti halnya ketentuan Pasal 5 Ayat (1) Undang-Undang Kekuasaan Kehakiman yang menyatakan bahwa hakim dan hakim konstitusi wajib menggali, mengikuti dan memahami nilai-nilai hukum dan rasa keadilan yang hidup dalam masyarakat". Menelusuri kenyataan yang ada di lapangan atau kondisi serta nilai-nilai yang ada di Kabupaten Yahukimo menunjukkan bahwa:

1. Pertama, fakta yang ada adalah setiap diadakan Pemilu nasional, akomodasi dan fasilitas pendukung dalam pelaksanaan pemilihan selalu datang terlambat dari pemerintah, yang disebabkan oleh jauhnya letak atau lokasi pemilihan berlangsung, belum lagi keterlambatan yang disebabkan kondisi cuaca yang buruk sehingga pesawat sering mengalami pembatalan penerbangan, bahkan menunggu berharihari.

2. Kedua, mahalnya akomodasi dan kecilnya pesawat memuat fasilitas dan akomodasi sehingga tahap pengiriman dilakukan berkala.

3. Ketiga, jauhnya medan yang ditempuh ke tempat lokasi pemilihan dengan menempuh perjalanan dengan jalan kaki.

Penggatian noken sebagai kotak suara merupakan bentuk adanya keinginan yang kuat dari masyarakat adat untuk ikut serta berpartisipasi menjadi bagian demokrasi NKRI. Sejarah mencatat bahwa jauh sebelum pemilihan umum nasional, di pegunungan Papua telah melaksanakan pemilihan dengan cara adat dalam proses pengankatan dan pemilihan kepala suku atau tetua adat (aklamasi). Ciri khas demokrasi noken adalah pesta bakar batu yang merupakan bagian dari pesta demokrasi pada proses pemilihan baik umum maupun nasional. Aklamasi dilakukan dengan cara

\footnotetext{
${ }^{33}$ Ibid, Bagir Manan
} 
musyawarah bersama. Musyawarah adalah model pemilihan bagian dari demokrasi Indonesia. Sekarang ini musyawarah mufakat mulai bergeser dengan menggunakan metode pemilihan nasional one man one vote oleh karena sangat tidak mungkin menyelenggarakan suatu pemilihan umum dengan cara musyawarah bersama dilakukan secara langsung serempak sedangkan wilayah nusantara sangat luas sekali dan jamak dengan berjuta-juta penduduk.

Meskipun pemerintah dalam upaya mengunifikasi peraturan perundang-undangan yang beragam ke dalam suatu ketetapan hukum positif yang berlaku bagi semua tanpa terkecuali. Namun realitas yang ada adalah masih adanya beberapa wilayah di Indonesia yang masih memegang peranan tradisional sesuai budayanya. Menurut Hans Kelsen:

"Suatu peraturan umum adalah adil jika ia benar-benar diterapkan kepada semua kasus yang menurut isinya peraturan harus diterapkan. Semua peraturan umum adalah tidak adil jika diterapkan pada satu kasus dan tidak diterapkan pada kasus lin yang serupa".

Artinya bahwa Hans Kelsen memberikan pengertian keadilan dalam arti legalitas adalah suatu kualitas yang berhubungan dengan isi dari suatu tatanan hukum positif, melainkan dengan penerapannya. Pemerintah tidak dapat memaksakan suatu peraturan hukum ke dalam suatu wilayah, sedangkan dalam wilayah tersebut masih ada atau masih hidup aturan hukum adat didalamnya. Jika dipaksakanpun akan timbul suatu ketidakadilan bagi masyarakat adat serta penolakan.

Mencermati amar putusan hakim konstitusi dalam perkara Nomor 47-81/PHPUA/VII/2009, merupakan pertimbangan yang benar dan tepat. Mahkamah Konstitusi mengesampingkan peraturan tertulis demi menegakkan keadilan. Keadilan bagi masyarakat hukum adat yang masih hidup di wilayah pegunungan. Berdasarkan pada UUD NRI Tahun 1945, Pasal 28 Ayat (1) yaitu “setiap orng berhak atas pengakuan, jaminan, perlindungan dan kepastian hukum yang adil serta perlakuan yang sama di hadapan hukum". Semua mempunyai hak yang sama sebagai warga negara Indonesia. 
Berdasarkan uraian tersebut di atas, maka dapat ketahui bahwa dasar pertimbangan hukum hakim konstitusi dalam Putusan MK NO 47-81/PHPU.AVII/2009 terkait dengan legitimasi sistem noken di Provinsi Papua, merujuk kepada pendapat Bagir Manan tidak terpenuhi, salah satunya yuridis yaitu terkait dengan tata cara pelaksanaan dengan menggunakan sistem pemilu noken sebagai pengganti kotak suara dan pengambilan suara secara transparan dengan prosedur musyawarah dan kemudian menyerahkan segala putusan kepada kepala suku, tidak sesuai dengan sistem pemilu nasional yang tata caranya didasarkan pada Pasal 22E Ayat (1) UUD NRI Tahun 1945 yaitu Pemilu dilaksanakan secara Luber-Jurdil; pertimbangan sosiologis tercermin pada kenyataan bahwa sesungguhnya pemerintah secara tegas menyatakan perlindungan dan penghormatan kepada masyarakat Propinsi Papua sebagai daerah istimewa dan memberikan legitimasi untuk melaksanakan pemilu dengan sistem noken. Unsur filosofis tercermin pada saat MK mengesampingkan peraturan tertulis demi menegakkan keadilan. Keadilan bagi masyarakat hukum adat yang masih hidup di wilayah pegunungan.

\section{B. Implikasi Pasca Putusan MK NO 47-81/PHPU.A-VII/2009 Terkait Dengan}

\section{Keberadaan Sistem Noken Di Provinsi Papua.}

Sebelum membahas implikasi pasca Putusan Mahkamah Konstitusi NO 4781/PHPU.A-VII/2009 terkait dengan berlakunya sistem noken di Provinsi Papua, berikut disampaikan amar putusan:

\section{Amar Putusan}

Mengingat pasal-pasal UUD NRI Tahun 1945, UU No. 24 Tahun 2003 tentang MK, UU Nomor 4 Tahun 2004 tentang Kekuasan Kehakiman, dan UU Nomor 10 Tahun 2008 tentang Pemilihan Umum Anggota DPR, DPD, dan DPRD yang telah dirubah dengan Perpu UU No 1 Tahun 2009 tentang Perubahan Atas UU No 10 Tahun 2008 tentang Pemilu Anggota DPR, DPD, dan DPRD, mengadili:

1. Dalam Eksepsi 
p-ISSN : 2541-2345, e-ISSN : 2580-8842

Menyatakan eksepsi Termohon dan Turut Termohon untuk calon Anggota DPD tidak dapat diterima

2. Dalam Pokok Perkara

Sebelum menjatuhkan putusan akhir dalam perkara ini:

a. Memerintahkan kepada KPU Kabupaten Yahukimo untuk melaksanakan pemungutan suara ulang pemulihan umum Calon Anggota DPD pada distrik-distrik yang ada: Distrik Ninia, Holuwon, Soba, Kayo, Hilipuk, Sobaham, Kwikna, Kabianggema, Lolat, Soloikma, Duram, Korupun, Sela, Kwelamdua, Langda, Bomela, S"mtamon, Dekai, Sumo, Obio, Seradala, Angruk, Walma, Pronggoli, Panggema, Ubahak, Yahuliambut, Kosarek, Nipsan, Talambo, Endomen, Fuldama, Kona, Dirwemna, Nalca, Ubalihi dan Distrik Hereapini dalam waktu paling lama 90 hari sejak putusan ini diucapkan;

b. Memerintahkan kepada KPU Kabupaten Yahukimo untuk melaksanakan pemungutan suara ulang Pemilu Calon Anggota DPD pada Distrik Kurima, Tangma, Ukha, Mugi, Yogosem, Werima, Pasema, Samenage, Silimo, Hogio, Amuma, Amuma, Musaik, Suru-Suru dan Distrik Wusama dalam wktu paling lambat 60 hari sejak putusn ini diucapkan;

c. Memerintahkan KPU Kab. Yahukimo untuk melaporkan penetapan hasil pemungutan dan penghitungan suara ulang tersebut kepada MK paling lambat dalam tenggat yang ditetapkan dalam amar putusan ini;

d. Menangguhkan berlakunya Keputusan KPU Nomor 255/Kpts/KPU/TAHUN 2009 tentang Penetapan dan Pengumuman Hasil Pemilihan Umum Anggota DPR, DPD dan DPRD Provinsi, DPRD Kab./Kota Secara Nasional dalam Pemilu Tahun 2009 sepanjang menyangkut hasil penghitungan suara calon Anggota DPD di Kab. Yahukimo, Provinsi Papua.

\section{Implikasi Pasca Putusan MK NO 47-81/PHPU.A-VII/2009 terkait dengan} Keberadaan Sistem Noken di Provinsi Papua. 
Mahkamah Konstitusi dalam perkara No 47-81/PHPU.A-VII/2009 telah menjatuhkan putusannya untuk melakukan pemungutan dan penghitungan suara ulang. Sesungguhnya dalam perkara NO. 47-81/PHPU.A-VII/2009 adalah merupakan sengketa Pemilu Calon Anggota DPD, DPR dan DPRD Provinsi dan DPRD Kab/Kota, namun kajian ini memfokuskan permasalahan pada sistem Pemilu dengan "kesepakatan warga" atau "aklamasi" atau yang terkenal dengan istilah noken, di mana dalam pertimbangannya, Mahkamah Konstitusi menghargai dan menghormati kekhasan adat masyarakat Kabupaten Yahukimo, Provinsi Papua:

"Menimbang bahwa Mahkamah berpandangan, Pemilu di Kab. Yahukimo tidak diselenggarakan berdasarkan peraturan perundang-undangan yang berlaku (UU No 10 Tahun 2008 yang telah diubah terakhir dengan Peraturan Pemerintah Pengganti UU No 1 Tahun 2009 tentang Perubahan Atas UU No 10 Tahun 2008 tentang Pemilu Anggota DPR, DPD, dan DPRD) karena tidak dengan cara pencontrengan surat suara, melainkan dengan "kesepakatan warga" atau "aklamasi" dan hasilnya tetap ke dalam rekapitulasi hasil pemungutan suara yang dilaksanakan pada tanggal 6 Mei 2009 di KPU Provinsi Papua. ${ }^{34}$

Namun justifikasi untuk legitimasi penerapan metode "Kesepakatan Warga" atau "Aklamasi" yang dikenal dengan istilah noken ini, oleh Mahkamah Konstitusi dalam putusan No. 47-81/PHPU.A-VII/2009 tanggal 09 Juni 2009:

"Menimbang bahwa Mahkamah dapat memahami dan menghargai nilai budaya yang hidup di kalangan masyarakat Papua yang khas dan menyelenggarakan pemilihan umum dengan cara atau sistem "kesepakatan warga" atau "aklamasi". Mahkamah menerima cara pemilihan kolektif ("kesepakatan warga" atau "aklamasi") yang telah diterima masyarakat Kabupaten Yahukimo tersebut, karena jika dipaksakan pemilihan umum sesuai dengan peraturan perundang-undangan yang berlaku dikhawatirkan akan timbul konflik diantra kelompok-kelompok masyarakat setempat. Mahkamah berpendapat, agar sebaiknya mereka tidak dilibatkan / dibawa ke sistem persaingan / perpecahan di dalam dan antar kelompok yang dapat mengganggu harmoni yang telah mereka hayati. ${ }^{35}$

\footnotetext{
${ }^{34}$ Putusan Mahkamah Konstitusi No. 47-81/PHPU.A-VII/2009, hal 46
}

${ }^{35}$ Op. Cit., Putusan MK, hal 46. 
Setiap putusan hakim merupakan yurisprudensi yang dapat dijadikan sebagai sumber hukum. Yurisprudensi berasal dari bahasa Latin "Jurisprudentia" yang berarti pengetahuan hukum (rechtsgeleerdheid). Dalam pengertian teknis yurisprudensi itu dimaksudkan sebagai putusan badan peradilan (hakim) yang diikuti secara berulangulang dalam kasus yang sama oleh para hakim lainnya sehingga dapat disebut sebagai "Rechtersrecht" atau "hukum ciptaan hakim/peradilan". 36 Selanjutnya menurut Hadjon, secara umum yang dimaksud dengan yurisprudensi adalah peradilan. Akan tetapi, dalam arti sempit yang dimaksud dengan yurisprudensi adalah ajaran hukum yang tersusun dari dalam peradilan, yang kemudian dipakai sebagai landasan hukum. ${ }^{37}$ Oleh sebab itu dalam perkara No 47-81/PHPU.A-VII/2009 tentang perselisihan hasil pemilu di Kab. Yahukimo, Provinsi Papua tersebut dalam pertimbangan yudisialnya berpandangan bahwa Mahkamah Konstitusi menghargai nilai budaya yang hidup di kalangan masyarakat Papua yang khas.

Implikasi pasca putusan MK NO 47-81/PHPU.A-VII/2009, maka perlu dilihat Pasal 24C Ayat (1) UUD NRI Tahun 1945, Juncto Pasal 10 Ayat (1) UU No. 24 Tahun 2003 tentang MK, Juncto Pasal 29 Ayat (1) dan (2) UU No. 48 Tahun 2009 tentang Kekuasaan Kehakiman menyebutkan bahwa:

"MK berwenang mengadili pada tingkat pertama dan terakhir yang putusannya final untuk menguji undang-undang terhadap Undang-Undang Dasar, memutus sengketa kewenangan lembaga negara yang kewenangannya diberikan oleh UUD, memutus pembubaran partai politik dan memutus sengketa hasil pemilihan umum". ${ }^{38}$

Berdasarkan ketentuan tersebut, maka dapat dikatakan bahwa putusan MK adalah bersifat final, artinya putusan MK telah memiliki kekuatan hukum tetap sejak dibacakan dalam persidangan MK, dan tidak ada upaya hukum lainnya. ${ }^{39}$ Putusan

\footnotetext{
${ }^{36}$ Ridwan. 2014. Hukum Administrasi Negara Edisi Revisi, PT. Rajagrafindo Persada, Jakarta, hal 64-65.

${ }^{37}$ Ibid.

${ }^{38}$ Pasal 24C Ayat (1) Undang-Undang Dasar Negara Republik Indonesia Tahun 1945, Juncto Pasal 10 Ayat (1) UndangUndang Nomor 24 Tahun 2003 tentang Mahkamah Konstitusi, Juncto Pasal 29 Ayat (1) dan (2) Undang-Undang Nomor 48 Tahun 2009 tentang Kekuasaan Kehakiman

39 Fajar Laksana Soeroso, "Pembangkangan Terhadap Putusan Mahkamah Konstitusi: Kajian Putusan Nomor 153/G/2011/PTUN-JKT". Jurnal Yudisial, Volume 6 Nomor 3 Desember 2013, Komisi Yudisial, 2013, Jakarta, hal 235. DOI: http://dx.doi.org/10.29123/jy.v6i3.100
} 
pengadilan yang telah memiliki kekutan hukum tetap memiliki kekuatan mengikat untuk dilaksanakan. Kekuatan mengikat putusan MK tidak hanya mengikat pihakpihak yang berperkara, namun mengikat semua orang yang berada di wilayah Republik Indonesia. Ia berlaku sebagaimana hukum diciptakan pembuat undang-undang. Hakim dikatakan sebagai negative legislator yang putusannya bersifat erga omnes, yang ditujukan kepada semua orang. ${ }^{40}$ Sehingga implikasi pasca Putusan Mahkamah Konstitusi No 47-81/PHPU.A-VII/2009 terkait dengan keberadaan sistem noken di Provinsi Papua, maka menjadi sah secara nasional, dan akan tetap hidup dan berkembang di tengah-tengah masyarakat adat Papua.

Berdasarkan uraian tersebut, maka dapat disimpulkan bahwa implikasi pasca Putusan MK NO 47-81/PHPU.A-VII/2009 terkait dengan keberadaan sistem noken di Provinsi Papua, merujuk kepada Pasal 24C Ayat (1) Undang-Undang Dasar Negara Republik Indonesia Tahun 1945, Juncto Pasal 10 Ayat (1) Undang-Undang Nomor 24 Tahun 2003 tentang Mahkamah Konstitusi, Juncto Pasal 29 Ayat (1) dan (2) UU No 48 Tahun 2009 tentang Kekuasaan Kehakiman, yang menyatakan bahwa putusan MK, adalah sah dan bersifat erga omnes, sehingga secara nasional, akan tetap hidup dan berkembang di tengah-tengah masyarakat adat Papua.

\section{PENUTUP}

Dasar pertimbangan hukum Hakim Konstitusi dalam Putusan MK NO 4781/PHPU.A-VII/2009 terkait dengan Legitimasi Sistem Noken Di Provinsi Papua, merujuk kepada pendapat Bagir Manan tidak terpenuhi, salah satunya yuridis yaitu terkait dengan tata cara pelaksanaan dengan menggunakan sistem pemilu noken sebagai pengganti kotak suara dan pengambilan suara secara transparan dengan prosedur musyawarah dan kemudian menyerahkan segala putusan kepada kepala suku, tidak sesuai dengan sistem pemilu nasional yang tata caranya didasarkan pada Pasal 22E Ayat (1) UUD NRI Tahun 1945 yaitu Pemilu dilaksanakan secara Luber-Jurdil; pertimbangan sosiologis tercermin pada kenyataan bahwa sesungguhnya pemerintah secara tegas

\footnotetext{
${ }^{40}$ Abdul Latif. 2009. Buku Ajar Hukum Acara Mahkamah Konstitusi, Total Media, Yogyakarta, hal 219.
} 
p-ISSN : 2541-2345, e-ISSN : 2580-8842

menyatakan perlindungan dan penghormatan kepada masyarakat Provinsi Papua sebagai daerah istimewa dan memberikan legitimasi untuk melaksanakan pemilu dengan sistem noken. Unsur filosofis tercermin pada saat Mahkamah Konstitusi mengesampingkan peraturan tertulis demi menegakkan keadilan bagi masyarakat hukum adat yang masih hidup di wilayah pegunungan.

Implikasi pasca Putusan MK NO 47-81/PHPU.A-VII/2009 terkait dengan keberadaan sistem noken di Provinsi Papua, merujuk kepada Pasal 24C Ayat (1) UUD NRI Tahun 1945, Juncto Pasal 10 Ayat (1) UU Nomor 24 Tahun 2003 tentang Mahkamah Konstitusi, Juncto Pasal 29 Ayat (1) dan (2) UU Nomor 48 Tahun 2009 tentang Kekuasaan Kehakiman, yang menyatakan bahwa putusan Mahkamah Konstitusi, adalah sah dan bersifat erga omnes, sehingga secara nasional, akan tetap hidup dan berkembang di tengah-tengah masyarakat adat Papua.

\section{DAFTAR PUSTAKA}

\section{Buku}

Admosudirdjo, Prajudi. 1997. Penegakan Hukum Di Lapangan Oleh Polri. Jakarta: Dinas Hukum Polri.

A Garner, Bryan. 1999. Black's Law Dictionary Seven Edition. West Group: ST. PAUL, MINN.

Asyhadie, H. Zaeni, dkk. 2015. Pengantar Hukum Indonesia. Jakarta: PT. Raja Grafindo Persada.

Aaron, Thomas J. 1991. Penyaringan Perkara Pidana Oleh Polisi (Diskresi Kepolisian), Cetakan Pertama. Jakarta: PT. Pradnya Paramita.

Ibrahim, Johnny. 2015. Teori Dan Metodologi Penelitian Hukum Normatif, Edisi Revisi. Malang: Bayumedia Publishing.

Marzuki, Peter Mahmud. 2006. Penelitian Hukum. Jakarta: Kencana.

Ridwan. 2014. Hukum Administrasi Negara Edisi Revisi. Jakarta: PT. Raja Grafindo Persada.

Sunggono, Bambang. 2002. Metode Penelitian Hukum. Jakarta, PT. Raja Grafindo Persada.

Sukanto, Soerjono. 1984. Pengantar Penelitian Hukum. Jakarta: UI Press. 
p-ISSN : 2541-2345, e-ISSN : 2580-8842

\section{Jurnal}

Affan Sulaeman, “Demokrasi, Partai Politik, dan Pemilihan Kepala Daerah". Cosmogov Jurnal Ilmu Pemerintahan. Volume. 1 Nomor 1, April 2015, Fakultas Ilmu Sosial Dan Ilmu Politik Universitas Padjadjaran, Bandung. DOI : https://doi.org/10.24198/cosmogov.v1i1.11857

Fajar Laksana Soeroso, "Pembangkangan Terhadap Putusan Mahkamah Konstitusi: Kajian Putusan Nomor 153/G/2011/PTUN-JKT”. Jurnal Yudisial, Volume 6 Nomor 3 Desember 2013, Komisi Yudisial, 2013, Jakarta, DOI: http://dx.doi.org/10.29123/jy.v6i3.100

Firman Floranta Adonara, "Prinsip Kebebasan Hakim Dalam Memutus Perkara Sebagai Amanat Konstitusi”. Jurnal Konstitusi, Volume 12, Nomor 2, Juni 2015, Mahkamah Konstitusi, 2015, Jakarta.

DOI: https://doi.org/10.31078/jk1222

Frenki, "Asas-Asas Dalam Pelaksanaan Pemilihan Umum di Indonesia Menurut Fiqh Siyasah”. Jurnal Hukum Ekonomi Syari'ah. Volume 8, Nomor 1 Tahun 2016, Universitas Muhamadiyah Purwokerto, 2016, Puwokerto. (DOI:https://doi.org/10.24042/asas.v8i1.1223)

Methodius Kossay, "Pemilu Sistem Noken Dalam Demokrasi Indonesia (Studi Kasus di Kabupaten Jayawijaya Provinsi Papua)”. Jurnal Serviens in Lumine Verietas, Fakultas Hukum Universitas Atma Jaya Yogyakarta, 2014, Yogyakarta.

Muhammad Fauzan Azim, "Pemilu dan Konstitusionalitas Sistem Noken". Turast Jurnal Penelitian dan Pengapdian Volume 1 Nomor 1 Tahun 2013, Universitas Islam Negeri Imam Bonjol, 2013, Padang.

Nelwan Ronsumbre, "Sistem Noken Papua : Manifestasi Demokrasi Berbasis Kearifan Lokal". Jurnal Sosial Politik Volume 5 Nomor 2 Tahun 2019, Universitas Padjajaran, 2019, Bandung. DOI: https://doi.org/10.22219/sospol.v5i2.7388

Oly Viana Agustine, "Implementasi Noken Sebagai Hukum Tidak Tertulis Dalam Sistem Hukum Nasional". Jurnal Rechtsvinding. Vol 8, Nomor 1 April 2019, Badan Pembinaan Hukum Nasional, 2019, Jakarta.

Ronsumbre, Nelwan, "Sistem Noken Papua : Manifestasi Demokrasi Berbasis Kearifan Lokal”. Jurnal Sosial Politik, Universitas Padjajaran Bandung Volume 5 Nomor 2 Tahun 2019.Yerianto, dkk. Peran Kepala Suku Dalam Sistem Noken Pada Pemilukada Di Distrik Kamu Kabupaten Dogiyai Provinsi Papua Tahun 2013 (Nusa Tenggara Timur,E Journal Politika Volume I Nomor 1, Fakultas Ilmu Sosial dan Ilmu Politik Universitas Udayana, 2016, Denpasar.

Waluyo, "Model Pemilu Dengan Sistem Noken Berbasis Budaya dan Kearifan Lokal". Jurnal Hukum Samudera Keadilan. Volume 13 Nomor 2 Juli-Desember 2018, Fakultas Hukum Universitas Samudra, 2018, Langsa. hal 296. DOI: https://doi.org/10.33059/jhsk.v13i2.1065. 